\title{
Anurofauna of an Atlantic Rainforest fragment and its surroundings in Northern Rio de Janeiro State, Brazil
}

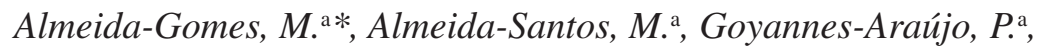 \\ Borges-Júnior, VNT. ${ }^{\text {, }}$ Vrcibradic, D. a, Siqueira, CC. ${ }^{\text {a,b }}$, Ariani, $C V^{\text {a }}$, \\ Dias, AS. a, Souza, VV. ${ }^{\text {a }}$ Pinto, RR. ${ }^{\text {c }}$,Van Sluys, M. ${ }^{\text {a }}$ and Rocha, CFD. ${ }^{\mathrm{a}}$

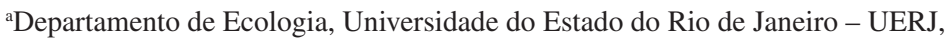 \\ Rua São Francisco Xavier, 524, CEP 20550-011, Rio de Janeiro, RJ, Brazil \\ 'Programa de Pós-graduação em Ecologia, Instituto de Biologia, Universidade Federal do Rio de Janeiro - UFRJ

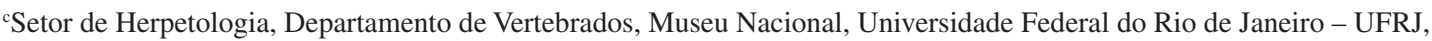 \\ CEP 20940-040, Rio de Janeiro, RJ, Brazil \\ *e-mail: almeida.gomes@yahoo.com.br
}

Received July 03, 2009 - Accepted October 19, 2009 - Distributed October 31, 2010

(With 1 figure)

\begin{abstract}
We carried out a study on the anurofaunal community from an Atlantic Forest fragment (Monte Verde mountains) and the surrounding area in Cambuci municipality, Rio de Janeiro State, Brazil, which constitutes one of the largest fragments remaining in the largely deforested landscape of the northern portion of the State. We combined three sampling methods: plot sampling, transects and pit-fall traps. We recorded twenty species of amphibians, of which only eleven were found within the forest fragment (and five of these also occurred in the surrounding matrix). Two of the species recorded in the present study (Crossodactylus sp. and Ischnocnema $\mathrm{cf}$. parva) may represent undescribed taxa. Our records expand the distribution range of one species (Scinax trapicheiroi) to the north, and fill a geographic distribution gap for another one (Ischnocnema oea). The estimated overall density of frogs living in the leaf litter of the fragment (based on results of plot sampling) was 3.1 individuals $/ 100 \mathrm{~m}^{2}$, with Haddadus binotatus being the most abundant species ( 2.4 individuals $/ 100 \mathrm{~m}^{2}$ ). Comparisons of our data with those of other studies suggest that anuran communities in forest fragments ca. 1,000 ha or smaller may be severely limited in their richness, and often include a large proportion of species tolerant to open areas, such as many hylids. Our results show the importance of increasing knowledge about the anurofaunal community of the northern portion of the State of Rio de Janeiro and preserve the forest remnants that still exist in the region.
\end{abstract}

Keywords: amphibian species, anuran community, abundance, habitat fragmentation.

\section{Anurofauna de um fragmento de Mata Atlântica e do seu entorno no Norte do Estado do Rio de Janeiro, Brasil}

\begin{abstract}
Resumo
Conduzimos um estudo de curta duração sobre a comunidade de anurofauna de um fragmento de Mata Atlântica (Serra do Monte Verde) localizado no município de Cambuci, Estado do Rio de Janeiro, Brasil, o qual constitui um dos maiores fragmentos remanescentes ainda existentes na paisagem amplamente desflorestada da porção norte do Estado. Utilizamos três métodos de amostragem combinados: parcelas, transectos e armadilhas de queda. Registramos vinte espécies de anfíbios, das quais apenas onze foram encontradas dentro do fragmento florestal (e dessas, cinco também ocorreram no seu entorno). Duas das espécies registradas no presente trabalho (Crossodactylus sp. e Ischnocnema cf. parva) podem representar táxons ainda não descritos. Nossos registros expandem a distribuição geográfica de uma espécie (Scinax trapicheiroi) para o norte e preenchem uma lacuna na distribuição de outra (Ischnocnema oea). A densidade total estimada de anfíbios anuros vivendo na camada de folhiço do fragmento (baseada nos resultados do método de plots) foi de 3,1 indivíduos $/ 100 \mathrm{~m}^{2}$, sendo Haddadus binotatus a espécie mais abundante $\left(2,4\right.$ indivíduos $\left./ 100 \mathrm{~m}^{2}\right)$. Comparações de nossos dados com os de outros estudos sugerem que comunidades de anuros em fragmentos florestais com cerca de 1.000 ha ou menos podem ser severamente limitados em sua riqueza e frequentemente incluem uma grande proporção de espécies tolerantes a ambientes abertos, como é o caso de vários hilídeos. Nossos resultados demonstram a importância de ampliar o conhecimento sobre a anurofauna da região norte do Estado do Rio de Janeiro e de conservar os poucos remanescentes florestais ainda existentes na região.
\end{abstract}

Palavras-chave: espécies de anfíbios, comunidade de anuros, abundância, fragmentação do habitat. 


\section{Introduction}

Amphibian declines are reported in several regions of the world and several factors are pointed as responsible for this process, such as habitat loss and fragmentation, contamination of water and soil by chemical pollutants, climate change, pathogens, and introductions of exotic species (Blaustein et al., 1994; Alford and Richards, 1999; Lips et al., 2005; Hamer and McDonnel, 2008; Laurance, 2008). These declines increase the importance of studies that provide support for amphibian conservation, especially in areas without previous knowledge of the local anurofauna (Rocha et al., 2003; Diniz-Filho et al., 2004).

Human activities are responsible for habitat fragmentation in several forest areas worldwide, and the persistence of species in a fragmented landscape may depend strongly on their tolerance to the surrounding matrix environment and on the structural and physiognomical characteristics of the latter (Gascon et al., 1999; Ricketts, 2001; Castro and Fernandez, 2004). Understanding the effects of forest fragmentation on amphibian community distributions are essential for conservation practices, as those animals are often severely affected by changes in the landscape (e.g. Blaustein et al., 1994; Silva et al., 2003; Pineda and Halffter, 2004). Amphibians have several features that make them vulnerable to habitat fragmentation, such as a moist and permeable skin (which makes them more susceptible to pollution and desiccation), a biphasic life cycle (in most species) with an aquatic larval stage and an adult land-dwelling or semi-aquatic stage, and a low dispersal ability (Duellman and Trueb, 1994; Blaustein et al., 1994; Silva et al., 2003). Some negative responses to habitat fragmentation that have been reported for amphibians include decreased diversity and abundance, changes in community composition, edge avoidance and reduced reproductive success (Marsh and Pearman, 1997; Gascon et al., 1999; Schlaepfer and Gavin, 2001; Funk and Mills, 2003; Neckel-Oliveira, 2004; Pineda and Halffter, 2004).

The northwestern portion of the State of Rio de Janeiro presents the landscape highly fragmented, with only one representative remnant of Atlantic Rainforest: the Monte Verde mountains, in the municipality of Cambuci (Attias et al., 2009) (Figure 1). That area is of special interest because it presently represents a virtual "island" of Atlantic forest surrounded by a matrix of pastures and cultivated fields. Nevertheless, there is no published information on the anurofauna for the northernmost portion of the State of Rio de Janeiro. In the present study, we present data on some community parameters such as species composition, richness, relative abundances and densities of the anuran community of the Monte Verde area and its surroundings.

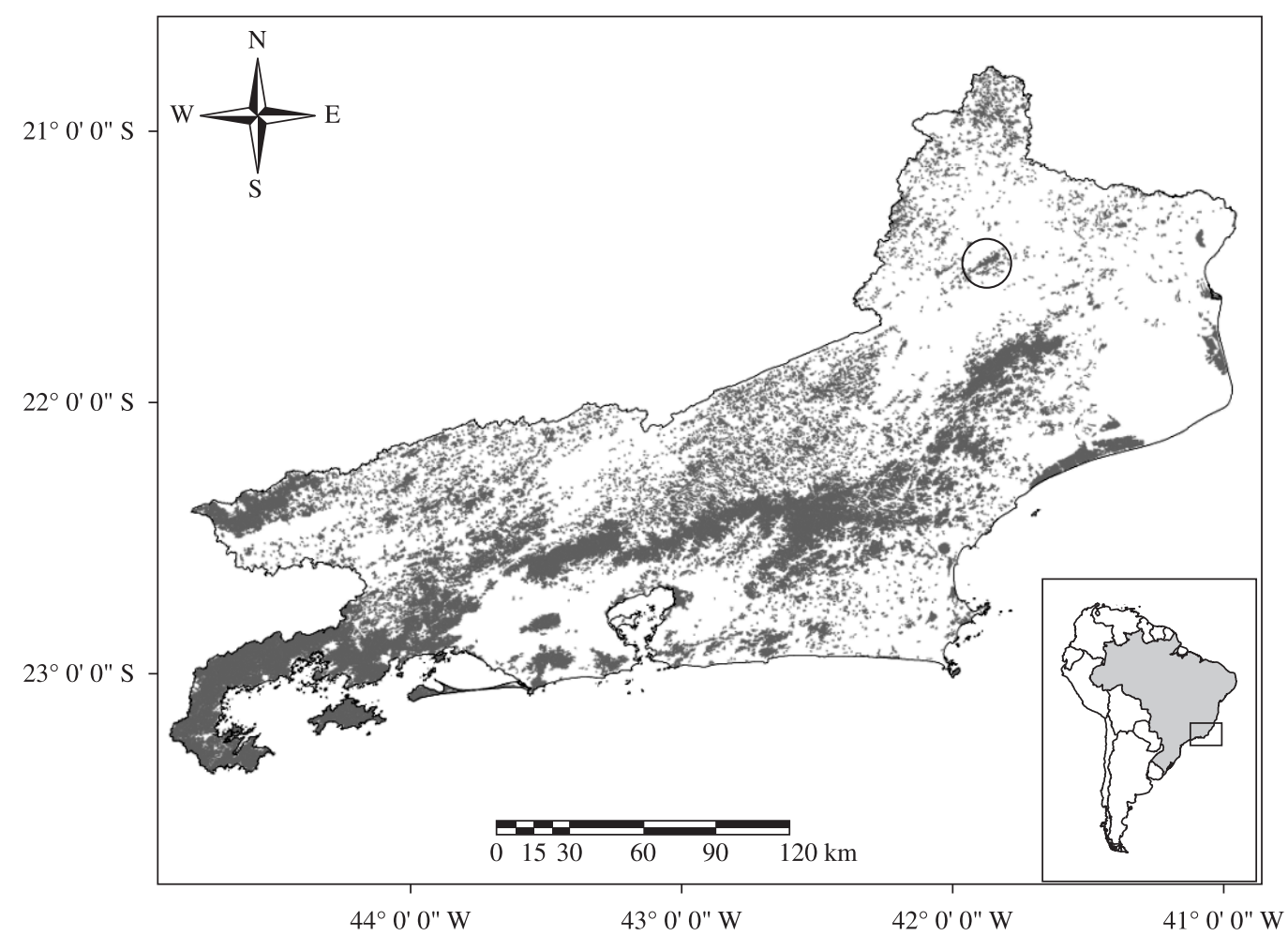

Figure 1. Location of the Monte Verde mountains (encircled) in the State of Rio de Janeiro, Brazil. Shaded areas correspond to forest fragments. 


\section{Material and Methods}

\subsection{Study area}

Fieldwork was carried out in and around a forest fragment $\left(21^{\circ} 29^{\prime} \mathrm{S}\right.$ and $\left.41^{\circ} 52^{\prime} \mathrm{W}\right)$ covering the Monte Verde mountains, in the municipality of Cambuci, State of Rio de Janeiro, southeastern Brazil. This fragment consists of about 1,000 ha of secondary Atlantic Rainforest (Semidecidual Seasonal Forest), being the largest forest fragment in the state's northernmost portion (i.e. north of the Paraíba do Sul River). The fragment's surroundings are dominated by pastures, with many scattered small forest fragments. Mean annual temperature in the area is $23-25^{\circ} \mathrm{C}$ and annual rainfall is $1,276 \mathrm{~mm}$, with the highest precipitation occurring between November and January and the lowest between May and September (Martorano et al., 2003; Attias et al., 2009).

\subsection{Data collection and analyses}

Surveys were carried out during September 2006 at altitudes between 100 and $650 \mathrm{~m}$, always by the same ten-person team. In order to obtain a representative dataset of the anurofauna for the study area, we used three sampling methods: large plots (Jaeger and Inger, 1994), visual encounter surveys (VES; Crump and Scott Jr., 1994) and pit-fall traps with drift fences (Corn, 1994). Besides, all frogs found during casual encounters were also collected. Plot sampling and transect searches carried out within the forest were done on different points, trying to cover a relatively large area of the fragment (the two sampling points most distant from each other were ca. $4 \mathrm{~km}$ apart).

The large-plot method was used only within the forest fragment. We established 30 quadrats of $5 \times 5 \mathrm{~m}\left(25 \mathrm{~m}^{2}\right)$ on the forest floor during the late afternoon. We marked the corners of each plot (or quadrat) with wooden stakes and the plot was completely enclosed with a $50 \mathrm{~cm}$ high soft plastic fence. The bottom of the fence was buried or attached to the ground to prevent animals from escaping the plot. After the sunset, the leaf litter inside each plot was carefully searched for about half an hour by a five-person crew wearing head lamps. During searches, stones and fallen logs and branches were overturned and rock crevices and spaces between tree roots were also carefully checked. Vertical tree trunks (up to a height of ca. $2 \mathrm{~m}$ ) and shrubs inside the plots were also examined for the presence of scansorial amphibians. Plot sampling was performed during five consecutive days with six quadrats examined per day, totaling $750 \mathrm{~m}^{2}$ of forest floor searched.

For the VES method, we carried out 150 transects of 30 minutes duration each, totalling 75 hours of sampling effort, during five days ( 15 hours per day, always by the same ten people). Transects were carried out both in the forest interior and in open areas surrounding the forest fragment (up to its edge), including perianthropic habitats. The same number of transects (50) was surveyed within each of three periods: diurnal (11:00 AM-4:30 PM), crepuscular (5:30 PM-6:30 PM) and nocturnal (7:30 PM-9:00 PM); each period was surveyed once per day by each of the ten observers. During each transect, the observer moved at a slow walking pace, carefully searching the surroundings for the presence of amphibians. In areas where the transects were made, all available microhabitats were carefully searched (e.g. leaf litter, water bodies, bromeliads, fallen logs, tree trunks, shrubs, rocks).

Three pit-fall trap systems were set within the forest fragment, at least $300 \mathrm{~m}$ apart from each other, and used for a total of 15 days. Each pit-fall trap system consisted of ten $30 \mathrm{~L}$ buckets buried in the ground, up to their rim, and set ca. $5 \mathrm{~m}$ apart, with soft plastic drift fences about $50 \mathrm{~cm}$ high extended between them. Six buckets were placed in line and the other four were placed at opposite sides of the fence, perpendicularly to the main axis. Pit-falls were checked once per day (always in the morning) and all frogs found in them were removed.

For an estimate of species composition and richness of the anuran community in the area we considered the species recorded by all three sampling methods, plus those collected during casual encounters. For estimates of litter frog density (individuals $/ 100 \mathrm{~m}^{2}$ ) we considered only the data obtained by large plot sampling, as this method has been the most frequently used in tropical forests worldwide (e.g. Allmon, 1991; Vonesh, 2001; Watanabe et al., 2005).

\section{Results}

We recorded a total of 20 species of anurans in the forest fragment studied and in the matrix that surrounds it (Table 1). The local frog community was dominated by members of the family Hylidae, represented by 12 species, most of which were associated with open habitats (Table 1).

The number of individuals and species sampled varied consistently depending on the sampling method used. In the plots we recorded 23 individuals belonging to just three species: Haddadus binotatus (Spix, 1824), Ischnocnema oea (Heyer, 1984) and Hypsiboas faber (Wied-Neuwied, 1821) (Table 1). The former two were always found on the ground, whereas the latter was only found perched on vegetation. The number of frogs per plot ranged from zero (21/30 or $70.0 \%$ of all plots) to five (1/30 or $3.3 \%$ of all plots) with a mean of $0.8 \pm 1.4$ frogs per plot. The overall frog density estimated from plot sampling was 3.1 individuals $/ 100 \mathrm{~m}^{2}$. Haddadus binotatus represented about $77 \%$ of all frogs found in plots, with an estimated density of 2.4 ind./100 $\mathrm{m}^{2}$. Ischnocnema oea and $H$. faber had much lower values for estimated density (0.4 and 0.3 ind./100 $\mathrm{m}^{2}$, respectively).

During transect sampling (VES) we recorded a total of 19 frog species at the forest fragment and at the surrounding matrix (Table 1). The most abundant species recorded in transects were Dendropsophus minutus (Peters, 1872) $(\mathrm{N}=25 ; 21.7 \%$ of all individuals found during transects) and Scinax fuscovarius (Lutz, 1925) $(\mathrm{N}=18 ; 15.6 \%)$, both of which were found only in open habitats. Most frogs were found during nocturnal samplings $(\mathrm{N}=100$, or $87.0 \%$ of individuals sampled), whereas 13 individuals (11.3\%) were found during crepuscular transects and only two (1.7\%) were found during diurnal transects (Table 2). 
Table 1. Number of individuals of each frog species sampled by each sampling method (Plots, Transects, Pit-falls) and by occasional collections (here called "extra") in an Atlantic Rainforest fragment (Monte Verde mountains) and its surroundings in Cambuci, southeastern Brazil.

\begin{tabular}{|c|c|c|c|c|c|}
\hline Species & Plots & Transects & Pit-falls & Extra & Total \\
\hline \multicolumn{6}{|l|}{ Amphibia: Anura } \\
\hline \multicolumn{6}{|l|}{ Brachycephalidae } \\
\hline Ischnocnema oea (Heyer, 1984) & 3 & 4 & - & - & 7 \\
\hline Ischnocnema cf. parva (Girard, 1853) & - & 1 & - & - & 1 \\
\hline \multicolumn{6}{|l|}{ Bufonidae } \\
\hline Rhinella crucifer ${ }^{* *}$ (Wied-Neuwied, 1821) & - & 1 & - & - & 1 \\
\hline \multicolumn{6}{|l|}{ Craugastoridae } \\
\hline Haddadus binotatus (Spix, 1824) & 18 & 8 & 5 & 9 & 40 \\
\hline \multicolumn{6}{|l|}{ Cycloramphidae } \\
\hline Thoropa miliaris ${ }^{*}($ Spix, 1824) & - & 14 & - & 2 & 16 \\
\hline \multicolumn{6}{|l|}{ Hylidae } \\
\hline Dendropsophus decipiens ${ }^{* *}($ Lutz, 1925) & - & 3 & - & - & 3 \\
\hline Dendropsophus elegans* (Wied-Neuwied, 1824) & - & 7 & - & - & 7 \\
\hline Dendropsophus minutus ${ }^{* *}$ (Peters, 1872) & - & 25 & - & - & 25 \\
\hline Hypsiboas albomarginatus ${ }^{* *}$ (Spix, 1824) & - & 2 & - & - & 2 \\
\hline Hypsiboas faber (Wied-Neuwied, 1821) & 2 & 14 & - & 1 & 17 \\
\hline Hypsiboas pardalis ${ }^{*}($ Spix, 1824) & - & 1 & - & 1 & 2 \\
\hline Hypsiboas semilineatus $^{* *}$ (Spix, 1824) & - & 2 & - & - & 2 \\
\hline Phyllomedusa burmeisteri Boulenger, 1882 & - & 1 & - & - & 1 \\
\hline Scinax flavoguttatus (Lutz and Lutz, 1939) & - & - & - & 2 & 2 \\
\hline Scinax aff. $x$-signatus ${ }^{* *}($ Spix, 1824) & - & 3 & - & - & 3 \\
\hline Scinax fuscovarius ${ }^{* *}($ Lutz, 1925) & - & 18 & - & 1 & 19 \\
\hline Scinax trapicheiroi* (Lutz, 1954) & - & 7 & - & - & 7 \\
\hline \multicolumn{6}{|l|}{ Hylodidae } \\
\hline Crossodactylus sp. & - & 2 & 4 & - & 6 \\
\hline \multicolumn{6}{|l|}{ Leptodactylidae } \\
\hline Leptodactylus ocellatus** (Linnaeus, 1758) & - & 1 & - & 1 & 2 \\
\hline Leptodactylus spixi** Heyer, 1983 & - & 1 & - & 1 & 2 \\
\hline Total & 23 & 115 & 9 & 18 & 165 \\
\hline
\end{tabular}

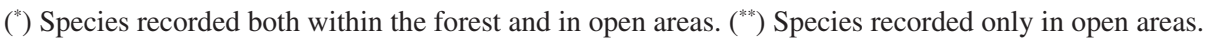

Nine individuals of only two species, Haddadus binotatus and Crossodactylus sp., were captured in the pit-fall traps (Table 1). Members of the latter species were all captured in a single system set close to a stream.

Although most of the sampling for the study was conducted within the forest, nine of the 20 species recorded were found only in open areas around the forest or at its border, whereas five others were found both within the forest and in open habitats (Table 1).

\section{Discussion}

Our results constitute the first approach to species composition of the anurofauna of the Cambuci region, with the local amphibian community being composed by at least 20 frog species. However, only 11 of these were recorded within the forest fragment, with the remaining species being associated with open and disturbed habitats. The frog community in the study area was dominated by species of the Hylidae family, most of which were associated with open areas. Most of the hylid species recorded in the present study are usually abundant in disturbed landscapes, where they commonly use permanent or temporary ponds for reproduction (e.g. Feio and Ferreira, 2005; Haddad and Prado, 2005; Abrunhosa et al., 2006; Lucas and Fortes, 2008). In fragmented landscapes, the surrounding matrix can constitute barriers for dispersal of forest frog species and, conversely, forested areas can restrict dispersal movements for species typical of open areas (Gascon et al., 1999; Dixo and Verdade, 2006). Such landscape heterogeneity thus potentially allows different forms of occupation by species of the local frog community (Guerry and Hunter Jr., 2002, Buskirk, 2005, Hillers et al., 2008), as observed in the present study. 
Table 2. Number of individuals of each frog species sampled during diurnal, crepuscular and nocturnal transects in a small Atlantic Rainforest fragment (Monte Verde mountains) and in its surroundings in Cambuci, Rio de Janeiro State, Brazil.

\begin{tabular}{|c|c|c|c|}
\hline Species & Diurnal & Crepuscular & Nocturnal \\
\hline \multicolumn{4}{|l|}{ Amphibia: Anura } \\
\hline Crossodactylus sp. & - & - & 2 \\
\hline Dendropsophus decipiens (Lutz, 1925) & - & - & 3 \\
\hline Dendropsophus minutus (Peters, 1872) & - & - & 25 \\
\hline Dendropsophus elegans (Wied-Neuwied, 1824) & - & - & 7 \\
\hline Haddadus binotatus (Spix, 1824) & - & 6 & 2 \\
\hline Hypsiboas albomarginatus (Spix, 1824) & - & - & 2 \\
\hline Hypsiboas faber (Wied-Neuwied, 1821) & - & 2 & 12 \\
\hline Hypsiboas pardalis (Spix, 1824) & - & - & 1 \\
\hline Hypsiboas semilineatus (Spix, 1824) & - & - & 2 \\
\hline Ischnocnema oea (Heyer, 1984) & 2 & - & 2 \\
\hline Ischnocnema cf. parva (Girard, 1853) & - & - & 1 \\
\hline Leptodactylus ocellatus (Linnaeus, 1758) & - & - & 1 \\
\hline Leptodactylus spixi Heyer, 1983 & - & - & 1 \\
\hline Phylomedusa burmeisteri Boulenger, 1882 & - & - & 1 \\
\hline Rhinella crucifer (Wied-Neuwied, 1821) & - & - & 1 \\
\hline Scinax aff. $x$-signatus (Spix, 1824) & - & - & 3 \\
\hline Scinax fuscovarius (Lutz, 1925) & - & - & 18 \\
\hline Scinax trapicheiroi (Lutz, 1954) & - & - & 7 \\
\hline Thoropa miliaris (Spix, 1824) & - & 5 & 9 \\
\hline Total & 2 & 13 & 100 \\
\hline
\end{tabular}

Preliminary data on amphibian richness (20 species) reported here for the 1,000 ha forest fragment of Monte Verde and its surroundings is comparable to those reported in previous studies carried out in and around other Atlantic Rainforest fragments. For instance, Almeida-Gomes et al. (2008) reported 15 frog species for another forest fragment (ca. 640 ha) and its surroundings in the State of Rio de Janeiro during a similar short-term survey. Another similar survey by Feio and Ferreira (2005) on two very small forest fragments (10 and 12 ha) in Minas Gerais State (SE Brazil) yielded 11 and 16 species, respectively, and 14 species were recorded during a one-year survey at a 515 ha fragment in the State of Paraíba (NE Brazil) by Santana et al. (2008). Lucas and Fortes (2008) recorded 20 and 24 frog species during one-year surveys in two forest fragments of ca. 1,300 ha (of which little more than half was composed of native vegetation) and ca. 300 ha, respectively, in southern Brazil. As in our study, the anuran family best represented in terms of species richness in those localities was the Hylidae. The observations above suggest that anuran communities in forest fragments of ca. 1,000 ha or less may be severely limited in their richness, and may often include a large proportion of species tolerant to open areas or ecotones, such as many hylids. It is also possible that the frog richness recorded in our study may reflect the period of the year at which the survey was realized (end of the dry season), and that a survey carried out within the wetter season could yield more species. Nevertheless, we lack data to confirm such a hypothesis.
Our survey provided some interesting new locality records for some species. Scinax trapicheiroi (Lutz, 1954) was originally described from a site in the municipality of Rio de Janeiro (Lutz, 1954). Subsequently, it has been reported from other localities both to the west and to the east of the type locality (Luna-Dias et al., 2009). Our record for Cambuci extends its geographic range some $160 \mathrm{~km}$ northeast of the previous easternmost reported locality, in Saquarema municipality (Luna-Dias et al., 2009). Ischnocnema oea was described from Santa Teresa, in the State of Espírito Santo (Heyer, 1984) and was until recently known only from the type locality. Silva-Soares et al. (2009) reported a specimen from Macaé de Cima, in the State of Rio de Janeiro, expanding the species' distribution some $335 \mathrm{~km}$ to the south. In the present study we report I. oea from a locality ca. $120 \mathrm{~km}$ north of Macaé de Cima, bridging the distribution gap and providing the second record for the State of Rio de Janeiro and the third reported locality for the species. Rhinella crucifer [as redefined by Baldissera et al. (2004)] was considered to have its southernmost limit of distribution in southern Espírito Santo State. Subsequently, it has been reported from four localities in the State of Rio de Janeiro, which extended its geographic range southwards (Marques et al., 2006; Silveira et al., 2009). The record from Cambuci provided here represents the fifth reported locality for $R$. crucifer in Rio de Janeiro, suggesting that this species may be widespread in the northern portion of the State. Additionally, the Crossodactylus specimens and one 
individual referred to as Ischnocnema cf. parva may represent two currently undescribed taxa (B. V. S. Pimenta and C. Canedo, pers. comm.).

The results of the present study add to the knowledge of the anuran fauna of an Atlantic Rainforest fragment and, particularly, of the little studied northern portion of Rio de Janeiro State. Of the 20 species recorded during the study, 11 were found within the forest fragment. Nevertheless, two of them (Ischnocnema cf. parva and Crossodactylus sp.) may represent species new to science, and one (Ischnocnema oea) was previously known from only two localities about $300 \mathrm{~km}$ apart, with its actual geographic distribution and status of its populations being currently unknown. This points to the importance of the conservation of the studied fragment which is one of the last representative remnants of the Atlantic rainforest in the largely deforested landscape of the northern region of Rio de Janeiro State.

Acknowledgements - The Critical Ecosystem Partership Funf (CEPF) at Conservation International and the Conselho Nacional de Desenvolvimento Científico e Tecnológico - CNPq provided financial support. The latter also provided research grants to C. F. D. Rocha (Processes No. 307 653/2003-0 and 476 684/2008-0) and M. Van Sluys (Process No. 301401/04-7). C. F. D. Rocha also benefited from the "Cientistas do Nosso Estado" Programme from Fundação Carlos Chagas Filho de Amparo à Pesquisa do Estado do Rio de Janeiro - FAPERJ (No. E-26/102.404/2009). During this study M. A. Gomes, V. N. T. Borges-Junior received Graduate fellowships from the Coordenação de Aperfeiçoamento de Pessoal de Nível Superior (CAPES) and C. C. Siqueira from the Fundação de Amparo à Pesquisa do Estado do Rio de Janeiro (FAPERJ). We also thank C. Canedo, B. V. S. Pimenta, S. P. Carvalho-e-Silva and M. C. S. Cardoso for helping with the identification of the frog species and F. L. Pessoa for preparing the map.

\section{References}

ABRUNHOSA, PA., WOGEL, H. and POMBAL Jr., JP., 2006. Anuran temporal occupancy in a temporal pond from the Atlantic rain forest, south-eastern Brazil. Herpetological Journal, vol. 16, no. 2 , p. $115-122$.

ALFORD, RA. and RICHARDS, SJ., 1999. Global amphibian declines: a problem in applied ecology. Annual Review of Ecology and Systematics, vol. 30, p. 133-165.

ALLMON, WD., 1991. A plot study of forest floor litter frogs, Central Amazon, Brazil. Journal of Tropical Ecology, vol. 7, no. 4 , p. 503-522.

ALMEIDA-GOMES, M., VRCIBRADIC, D., SIQUEIRA, CC., KIEFER, MC., KLAION, T., ALMEIDA-SANTOS, P., NASCIMENTO, D., ARIANI, CV., BORGES-Jr., VNT., FREITAS-FILHO, RF., VAN SLUYS, M. and ROCHA, CFD., 2008. Herpetofauna of an Atlantic rainforest area (Morro São João) in Rio de Janeiro State, Brazil. Anais da Academia Brasileira de Ciências, vol. 80, no. 2, p. 291-300.

ATTIAS, N., RAÍCES, DSL., PESSOA, FL., ALBUQUERQUE, H., JORDÃO-NOGUEIRA, T., MODESTO, TC. and BERGALLO, HG., 2009. Potential distribution and new records of Trinomys species (Rodentia: Echimyidae) in the State of Rio de Janeiro. Zoologia, vol. 26, no. 2, p. 305-315.
BALDISSERA, FA., CARAMASCHI, U. and HADDAD, CFB., 2004. Review of the Bufo crucifer species group with the description of two new related species (Amphibia, Anura, Bufonidae). Arquivos do Museu Nacional do Rio de Janeiro, vol. 62 , no. 3 , p. $255-282$

BLAUSTEIN, AR., WAKE, DB. and SOUSA, WP., 1994. Amphibian declines: judging stability, persistence, and susceptibility of populations to local and global extinctions. Conservation Biology, vol. 8 , no. 1 , p. $60-71$

BUSKIRK, JV., 2005. Local and landscape influence on amphibian occurrence and abundance. Ecology, vol. 86, no. 7, p. 1936-1947.

CASTRO, EBV. and FERNANDEZ, FAS., 2004. Determinants of differential extinction vulnerabilities of small mammals in Atlantic forest fragments in Brazil. Biological Conservation, vol. 119 , no. 1 , p. 73-80.

CORN, PS., 1994. Straight-line drift fences and pitfall traps. In HEYER, WR., DONNELY, MA., ROY, WM., HAYEK, LC. and FOSTER, MS., eds. Measuring and Monitoring Biological Diversity: Standard Methods for Amphibians. Washington, DC: Smithsonian Institution Press. p. 109-117.

CRUMP, ML. and SCOTT Jr., NJ., 1994. Visual encounter surveys. In HEYER, WR., DONNELY, MA., ROY, WM., HAYEK, LC. and FOSTER, MS., eds. Measuring and Monitoring Biological Diversity: Standard Methods for Amphibians. Washington, DC: Smithsonian Institution Press. p. 84-92.

DINIZ-FILHO, JAF., BINI, LM., VIEIRA, CM., SOUZA, MC., BASTOS, RP., BRANDÃO, D. and OLIVEIRA, LG., 2004. Spatial patterns in species richness and priority areas for conservation of anurans in the Cerrado region, Central Brazil. Amphibia-Reptilia, vol. 25 , no. 1 , p. $63-75$

DIXO, M. and VERDADE, VK., 2006. Herpetofauna de serrapilheira da Reserva Florestal de Morro Grande, Cotia (SP). Biota Neotropica, vol. 6, no. 2. Available from: <http://www. biotaneotropica.org.br/v6n2/pt/abstract?article+bn0080602200 6.> Access in: 10/07/2009

DUELLMAN, WE. and TRUEB, L., 1994. Biology of amphibians. Baltimore: The Johns Hopkins University Press. 670 p.

FEIO, RN. and FERREIRA, PL., 2005. Anfíbios de dois fragmentos de Mata Atlântica no municipio de Rio Novo, Minas Gerais. Revista Brasileira de Zoociências, vol. 7, no. 1, p. 121-128.

FUNK, WC. and MILLS, LS., 2003. Potential causes of population declines in forest fragments in an Amazonian frog. Biological Conservation, vol. 111, no. 2, p. 205-214.

GASCON, C., LOVEJOY, TE., BIERREGAARD, RO., MALCOM, JR., STOUFFER, PC., VASCONCELOS, H., LAURANCE, WF., ZIMMERMAN, B., TOCHER, M. and BORGES, S., 1999. Matrix habitat and species richness in tropical forest remnants. Biological Conservation, vol. 91, no. 2-3, p. 223-229.

GUERRY, AD. and HUNTER Jr., ML., 2002. Amphibian distributions in a landscape of forests and agriculture: an examination of landscape composition and configuration. Conservation Biology, vol. 16 , no. 3 , p. $745-754$

HADDAD, CFB. and PRADO, CPA., 2005. Reproductive modes in frogs and their unexpected diversity in the Atlantic forest of Brazil. Bioscience, vol. 55, no. 3, p. 207-217. 
HAMER, AJ. and McDONNEL, MJ. 2008. Amphibian ecology and conservation in the urbanizing world: A review. Biological Conservation, vol. 141, no. 10, p. 2432-2449.

HEYER, WR., 1984. Variation, systematics, and zoogeography of Eleutherodactylus guentheri and closely related species (Amphibia: Anura: Leptodactylidae). Smithsonian Contributions to Zoology, vol. 402, p. 1-42.

HILLERS, A., VEITH, M. and RÖDEL, MO., 2008. Effects of forest fragmentation and habitat degradation on West African leaflitter frogs. Conservation Biology, vol. 22, no. 3, p. 762-772.

JAEGER, RG. and INGER, RF., 1994. Quadrat sampling. In: HEYER, WR., DONNELY, MA., ROY, WM, HAYEK, LC. and FOSTER, MS., eds. Measuring and Monitoring Biological Diversity: Standard Methods for Amphibians. Washington DC: Smithsonian Institution Press, p. 97-102.

LAURANCE, WF., 2008. Global warming and amphibian extinctions in eastern Australia. Austral Ecology, vol. 33, no. 1, p. 1-9.

LIPS, KR., BURROWES, PA., MENDELSON III, JR. and PARRA-OLEA, G., 2005. Amphibian declines in Latin America: widespread population declines, extinctions, and impacts. Biotropica, vol. 37, no. 2, p. 163-165.

LUCAS, EM. and FORTES, VB., 2008. Frog diversity in the Floresta Nacional de Chapecó, Atlantic Forest of southern Brazil. Biota Neotropica, vol. 8, no. 3, p. 51-61.

LUNA-DIAS, C., CARVALHO-E-SILVA, SP. and CARVALHOE-SILVA, AMPT., 2009. Amphibia, Anura, Hylidae, Scinax trapicheiroi: Distribution extension. Check List, vol. 5, n. 2, p. $251-253$.

LUTZ, B., 1954. Anfíbios anuros do Distrito Federal. Memórias do Instituto Oswaldo Cruz, vol. 52, no. 1, p. 155-197.

MARQUES, RA., ANNUNZIATA, BB. and CARVALHO-ESILVA, AMPT., 2006. Geographic distribution. Bufo crucifer. Herpetological Review, vol. 37, no. 1, p. 98.

MARSH, DM. and PEARMAN, PB., 1997. Effects of habitat fragmentation on the abundance of two species of Leptodactylidae frogs in the Andean montane forest. Conservation Biology, vol. 11, no. 6 , p. $1323-1328$.

MARTORANO, LG., ROSSIELLO, ROP., MENEGUELLI, NA., LUMBRERAS, JF., VALLE, LSS., MOTTA, PEF., REBELLO,
ERG., SAID, UP. and MARTINS, GS., 2003. Aspectos climáticos do noroeste fluminense. Rio de Janeiro: Embrapa Solos. 31 p.

NECKEL-OLIVEIRA, S. 2004. Effects of landscape change on clutches of Phyllomedusa tarsius, a neotropical treefrog. Biological Conservation, vol. 118, no. 1, p. 109-116.

PINEDA, E. and HALFFTER, G., 2004. Species diversity and habitat fragmentation: frogs in a tropical montane landscape in Mexico. Biological Conservation, vol. 117, no. 5, p. 499-508.

RICKETTS, TH., 2001. The matrix matters: effective isolation in fragmented landscapes. American Naturalist, vol. 158, no. 1, p. 87-99.

ROCHA, CFD., BERGALLO, HG., VAN SLUYS, M. and ALVES, MAS., 2003. A biodiversidade nos grandes remanescentes florestais do Estado do Rio de Janeiro e nas restingas da Mata Atlântica. São Paulo: Rima. 160 p.

SANTANA, GG., VIEIRA, WLS., PEREIRA FILHO, GA., DELFIM, FR., LIMA, YC. and VIEIRA, KS., 2008. Herpetofauna em um fragmento de Floresta Atlântica no Estado da Paraíba, Região Nordeste do Brasil. Biotemas, vol. 21, no. 1, p. 75-84.

SCHLAEPFER, MA. and GAVIN, TA., 2001. Edge effects on lizards and frogs in tropical forest fragments. Conservation Biology, vol. 15, no. 4, p. 1079-1090.

SILVA, M., HARTLING, LA., FIELD, SA. and TEATHER, K., 2003. The effects of habitat fragmentation on amphibian species richness of Prince Edward Island. Canadian Journal of Zoology, vol. 81 , no. 4 , p. 563-573.

SILVA-SOARES, T., FERREIRA, RB. and COSTA, PN., 2009. Geographic distribution. Ischnocnema oea. Herpetological Review, vol. 40, no. 1, p. 108-109.

SILVEIRA, AL., SALLES, ROL. and PONTES RC., 2009. Primeiro registro de Rhinella pombali e novos registros de $R$. crucifer e $R$. ornata no Estado do Rio de Janeiro, Brasil (Amphibia, Anura, Bufonidae). Biotemas, vol. 22, no. 4, p. 231-235.

VONESH, JR., 2001. Patterns of richness and abundance in a tropical African leaf-litter herpetofauna. Biotropica, vol. 33, no. 3 , p. $502-510$.

WATANABE, S., NAKANISHI, N. and IZAWA, M., 2005. Seasonal abundance in the floor-dwelling frog fauna on Iriomote Island of the Ryuku Archipelago, Japan. Journal of Tropical Ecology, vol. 21 , no. 1, p. 85-91. 